AperTO - Archivio Istituzionale Open Access dell'Università di Torino

\title{
Collective/Abstract in Morphology
}

\section{This is the author's manuscript}

Original Citation:

Availability:

This version is available http://hdl.handle.net/2318/1735242

since 2021-01-22T14:03:42Z

Publisher:

Oxford University Press

Published version:

DOI:10.1093/acrefore/9780199384655.013.594

Terms of use:

Open Access

Anyone can freely access the full text of works made available as "Open Access". Works made available under a Creative Commons license can be used according to the terms and conditions of said license. Use of all other works requires consent of the right holder (author or publisher) if not exempted from copyright protection by the applicable law. 


\section{Collective / Abstract in Morphology}

Livio Gaeta

\section{Summary}

The two labels collective and abstract have been used for referring to properties and categories relevant at different levels. In particular, while the term collective is normally used in connection with number and plurality referring to a plurality presented as a homogeneous group of entities, the term abstract makes general reference to processes of nominalization from different source classes, and especially verbs and adjectives. In the passage to the nominal domain verbal properties are partially lost while new nominal properties are acquired. Although the morphological processes covered by the two labels apparently depict different onomasiological domains, there is in fact an area where they systematically overlap and for this reason it seems convenient to treat them in the same chapter.

Keywords: Verb, Noun, Lexical Class, Nominalization, Abstract, Collective, Result, Argument, Number, Aspect

\section{The value of abstract and collective in morphology}

The two labels abstract and collective have been used for referring to properties and categories relevant at different levels. In particular, while the term collective is normally used in connection with number and plurality, the term abstract makes general reference to processes of nominalization from different source classes, and especially verbs and adjectives. Although the morphological processes covered by the two labels apparently depict different onomasiological domains, there is in fact an area where they systematically overlap and for this reason it seems convenient to treat them in the same chapter. This will be illustrated below with the help of concrete examples drawn from a number of languages. In the following paragraphs, abstracts first and then collectives will be discussed in the two domains usually identified in morphology, namely inflection and wordformation. As is well-known, they are distinguished by their functional purpose insofar as inflection produces word-forms to be used in syntax while derivation produces new lexemes serving for lexical enrichment. On the other hand, they can be taken to form a unique component insofar as they usually exploit similar encoding techniques. The boundaries are not always easy to draw, but I will generally take it for granted that they constitute the two extreme poles of a continuum with a number of in- 
between cases which also partially result from diachronic processes. This is especially true for collectives, while abstracts will be mainly investigated with regard to derivational processes although it will be shown that the continuum inflection/derivation is of relevance also in this latter case.

\section{The term abstract in morphological modeling}

While the term abstract displays a varied usage in inflectional morphology and is often specific of different theoretical constellations (see Haspelmath 2009 for a discussion of abstract cases), it usually identifies a homogeneous set of phenomena in word-formation. In particular, the term abstract has been used in the Greco-Latin philosophical tradition to identify names referring to universal concepts or ideas such as 'beauty' in order to distinguish them from concrete instantiations like 'beautiful' which are immediately applicable to concrete individuals (cf. Gruppe 1831, Jespersen 1924: 133, see Rainer 1996 for a historical reconstruction). From this the leap to considering as abstract those nouns which are derived by means of a metaphorical process of objectification is not big: Paul ([1880] 1891: 418) maintains that abstract nouns "like the substantival denotations of qualities must owe their origin to a metaphor only, the activity being apprehended under the category of the thing". The implicit assumption is that verbs as well as adjectives typically encode activities or natural qualities which are opposed to "things", i.e. material objects, typically designated by nouns. This process of objectification, however, brings about abstract nouns which stand in contrast to the typical nouns referring to concrete objects.

\subsection{Abstract nouns in morphology}

Quite in line with Paul's traditional view, the label abstract identifies nouns deriving from verbs and adjectives (and to a certain extent also from nouns) which result from a process of reification (cf. Langacker 1987: 57) or hypostatization (cf. Mackenzie 2004: 974) of their bases. In particular, adopting Lyons' (1977: 442-446) tripartite ontological distinction between first-, second-, and thirdorder entities it has been suggested to consider abstract nouns as second-order nouns, because they share their referential type with verbs which prototypically refer to entities that occur in time such as events, processes, etc. At the same time, they share their prototypical mode of linguistic encoding with first-order entities referring to entities that exist in time such as objects, places, etc. In this group, we can include simplexes like crime or event, but also suffixed nouns like assassination or 
occurrence. In this latter case, relocating the referential type of a second-order entity in the encoding packaging typical of first-order entities is held to have the effect of abstracting away from essential features of second-order entities such as temporal and aspectual properties. Such process of abstraction is metaphorically equated to a reification because the nominal packaging attains an “objectification" or hypostatization by attributing a certain number of concrete referential properties to the nominalized derivative such as the possibility of being pluralized, of appearing as a participant or "prop" in a discourse, etc. Another way to look at this process of abstraction is summarized by Porzig's (1930-31) classical definition of abstract nouns as 'names for sentence contents' (Namen für Satzinhalte) or action nominals, although in this latter view no clear distinction is made with regard to other deverbal nouns like the agent nouns (cf. Trost 1976).

Depending on the base category, one traditionally distinguishes different processes of transcategorization, and in particular deverbal nouns - also called action nominals - presenting a wide typology of cases like action nouns, event nouns, state nouns, etc. (cf. Comrie \& Thompson 2007 for a survey), and deadjectival and denominal nouns which are often referred to respectively as quality or property and status nouns. Although these derivatives share a common transpositional meaning insofar as their effect consists in changing the input word-class (cf. Malchukov 2004 and Lehmann 2015 for a discussion of possible derivational meanings), they often reflect different derivational processes, especially in those languages in which verbs and adjectives are clearly distinct word-classes. In what follows they will be treated separately, but possible commonalities will be hinted at.

\subsubsection{Deverbal nouns and typification}

In a typologically oriented perspective, it has been suggested to view any formal structure reflecting a predication which appears reduced in its illocutive force as resulting from a process of nominalization or typification insofar as it gives up parts of its prototypical features concerning finiteness, tense, etc. (cf. Lehmann 1982, Mackenzie 2007). Accordingly, it can be put on a scale of typification which expresses its degree of reduction or loss of individuation in terms of finiteness features and contextually of illocutive force. Thus, we can imagine a whole hierarchy starting with a declarative sentence like Donald appears in court which displays the highest illocutive force and all finiteness features. Through intermediate stages like That Donald appear in court is a necessary condition for his being granted bail in which the illocutive force is essentially lower but finiteness features are present (for the role of the subjunctive, cf. Aarts 2012), the hierarchy ends with the 
completely typified nominalization Donald's appearance in court in which no finiteness features are present and the illocutive force is reduced insofar as the abstract noun gives rise to a concept "that is not specific to the situation at hand" (Mackenzie 2007: 219). Accordingly, it lacks a specific individuation in contrast to the declarative sentence and can be used in combination with any kind of so-called container predicate (cf. Bartsch 1986, Gaeta 2015): Donald's appearance in court surprised the audience / normally creates tension in the audience / was not possible for security reasons. In this regard, it has been shown that such a typification accounts for the effects of nominalizations in headlines introducing a concept that will be further detailed in the newspaper article to follow and more intriguingly - for their use to withdraw from reality and thereby mystify the reader (cf. Mackenzie 2007: 219 for discussion).

It is important to stress that typification is normally accompanied by the reduction of the properties characterizing the source category, the verb, while at the same time the properties characterizing the target category, the noun, are correspondingly increased. Furthermore, in one and the same language several different operations can often be observed which express the typification of predicates whereby only those at the nominal end of the scale are to be attributed to derivation proper. Accordingly, the English gerund preserves tense as in Donald's having appeared in court surprised the audience: the presence of the perfect gerund forces a factive interpretation and blocks the negation of the container predicate: *Donald's having appeared in court was not possible for security reasons. In fact, the gerund is normally held to be part of inflection in contrast to the derivative appearance which cannot express any inflectional trait typical of the verbs.

This case nicely portrays the inflection/derivation continuum, insofar as the English gerund goes back to an old Germanic suffix forming verbal nouns which is nowadays attributed to the inflectional paradigm as a non-finite form of the verb. It is interesting to observe that also the opposite phenomenon can take place, namely a suffix originally used for a non-finite form of the verb which is subsequently employed to derive verbal nouns. In this regard, the so-called long infinitive of Romanian can be mentioned, which goes back to the old Latin infinitive (e.g., amā-re 'to love', finī$r e$ 'to finish', exprime-re 'to express', etc.). Here, the suffix -re has been re-used to form abstract nouns (1a), which can be normally pluralized (1b) and are usually blocked by the occurrence of other abstract nouns (1c) in neat contrast with typical inflectional forms like English appearing which is not blocked by the occurrence of appearance (see Gaeta 2015 for the details), and in in fact in Latin the abstract noun mors 'death' did not block the formation of the infinitive mori 'to die':

(1) a. a exprima 'to express' $\rightarrow$ exprimare 'expression'

a învăţa 'to learn' $\rightarrow$ învăţare 'acquisition' 
b. cântare 'singing, song' $\rightarrow$ cântări 'songs'

demolare 'demolition' $\rightarrow$ demolari 'demolitions'

c. a muri 'to die' $\rightarrow$ *murire / moarte 'death'

a ajuta 'to help' $\rightarrow$ *ajutare / ajutor 'help'

\subsubsection{The encoding of arguments}

A further issue connected with typification is related to the expression of verbal arguments which in fact can be dropped or expressed differently from the way they are normally expressed in individuated sentences. It is the merit of Koptjevskaja-Tamm's (1993) investigation to have shown on the basis of a large-scale language sample that the expression of verbal arguments in abstract nouns is normally modeled after the way arguments are marked in their sentential usage, or after the way in which genitive-like (or adjective-like) dependents in noun phrases are expressed, or after a mixture of the two patterns. This variation is typologically ordered insofar as the less typified nominalizations are closer to the sentential pole while the more typified ones are normally placed closer to the genitivelike pattern. Accordingly, in Korean deverbal nouns are formed by means of the suffixes - $(\breve{u}) m$ and $k i$ depending on the factivity of the typified expression (cf. Koptjevskaja-Tamm 1993: 90-91):

(2) a. John i Mary eke choek ŭl cu-əs'-ta

John NOM Mary DAT book ACC give-PAST-FIN

'John gave a book to Mary'.

b. [Kŭnyə ka motŭn ton ŭl kacy-əs'-ki] t'cemun e kŭ nŭn kŭny ka pilyoh-ces'-ta. she NOM all money ACC have-PAST-AN reason in he NOM she ACC need-PAST-FIN 'He needed her because she had all the money'.

Paralleling the sentential marking of the finite clause in (2a), the arguments depending on the action noun kacyas ' $k i$ 'possession' in (2b) replicate the same case-markers and the same SOV word order. Koptjevskaja-Tamm (1993: 91) remarks that in Korean the only real difference between finite clauses and constructions containing action nouns consists of "the impossibility of using topic particles in the latter, as well as in all other types of subordinate clauses". Again, this shows that the constructions 
containing action nouns are more typified than their corresponding finite clauses because topics are typically only possible in independent clauses displaying a full illocutive force.

In contrast to Korean, the so-called long infinitives of Romanian mentioned in §3.1.1 offer the typical nominal type mirroring the nominal phrases encoding possession (3a), and are clearly distinct from the true (so-called short) infinitives (3b) and the so-called supines (3c) which display sentential syntax (see Gaeta 2015 for the details):

(3) a. invăţare-a limbilor străine de către englezi acquisition-DEF languages.DEF.PL.GEN strange.F.PL of toward English.M.PL 'the acquisition of the foreign languages by the English'

b. El vorbeşte fără a comunica nicio idee. he talks without to communicate no one idea 'He talks without conveying any idea'.

c. Aici e de câştigat un premiu. here is of win.SUP a prize 'There is a prize to be won here'.

In general, the polarization of verbal vs. nominal properties across constructions belonging either to the sentential or to the nominal type cross-cuts the inflection-derivation continuum insofar as on the sentential pole more infinitive-like verbal nouns are found while on the nominal pole more typical action nouns occur (cf. Koptjevskaja-Tamm 1993: 265).

A certain amount of literature (cf. Grimshaw 1990 and Haspelmath \& Sims 2010: 254, Alexiadou 2010 for discussion) has been devoted to the discussion whether different types of abstract nouns have to be assumed depending on the operation involved, namely the simple event noun (4a-b) and the complex event noun (4c):

(4) a. I have an examination tomorrow.

b. I have three examinations tomorrow.

c. The vet's careful examination of Fido's eyes took a long time.

d. *an examination of Fido's eyes by the vet

e. *three examinations of Fido's eyes by the vet 
In particular, the difference centers on the enhanced occurrence of verbal properties in complex event nouns which normally involve explicit arguments, have to be definite (4d) and cannot be pluralized (4e), while this is not true for simple nouns which behave more like ordinary nouns. Under this viewpoint, the occurrence of verbal arguments is made revealing of the different type of event noun involved. It must be added, however, that both the restrictions on definiteness and on pluralization are far less strict than one might think of insofar as expanding the context of the two incriminated sentences has the effect of clearly improving their acceptability:

(5) a. An examination of Fido's eyes by the vet revealed a prolapse of the third eyelid.

b. Three separate examinations of Fido's eyes by different vets each led to the same diagnosis.

In short, other factors are plausible to play a role in this connection, and in the first place the possibility of expressing verbal plurality, i.e. multiplicity of events, by means of the nominal morphology as we will see in $\S 2.1 .3$.

\subsubsection{Semantic shifts}

The reduction of verbal arguments represents one of the effects of typification insofar as the predicate becomes less and less instantiated also in dependence of this reduction. In concomitance with this, a further phenomenon takes place which also calls into play the concrete / abstract cline. In fact, a semantic shift can be observed from an abstract, predicate-referring eventive value to a concrete value referring to the (abstract or concrete) result of a predicate as in construction 'act of constructing' $>$ 'what has been constructed', or to the persons responsible of a certain predicate as in administration 'act of administrating' > 'persons responsible for administrating', or even to the place where a certain predicate is meant to take place. For instance, the expression New York's administration / the administration of New York can - depending on the context - refer to the activity, or to the persons responsible for the activity thus displaying a collective value which refers to a well-defined plurality of individuals.

The spectrum of the possible meaning extensions is quite rich and several different mechanisms have been proposed for this case of regular polysemy in the sense of Apresjan's (1974), who basically associates the range of meanings displayed by a word with its range of frequency. A first account relies on the traditional idea of an abstract / concrete semantic cline and explains the polysemy by making reference to the abstract meaning carried by abstract nouns, which - as second order noun - 
renders them unfit with regard to the nominal prototype consisting of first order nouns. Accordingly, a number of concrete meaning extensions come about which have the effect of improving the categorial status of the abstract nouns from the semantic point of view. The extensions follow a metonymic path, insofar as the abstract nouns turn out to express the (abstract, i.e. fact/state, or concrete) result of an activity (6a), or the place where it is generally supposed to take place (6b), or the time or manner of its unwinding (6c), or the means used to carry it out (6d), or the persons who normally carry it out (6e), etc. (cf. Bauer 1983: 185, and Rainer 1996 for a historical reconstruction of the question):

(6) a. I have received a brief communication from her.

b. His accommodation was a luxurious flat in the city.

c. The dean slept during the discussion.

d. Communications with the capital have been restored.

e. The government has cut the salaries.

On the other hand, given the high frequency of the result meaning, it has been suggested that this might be due to an inner ambiguity of the derivative, i.e. as an ambiguity available by virtue of the semantics inherent in the noun itself as it basically relates to the availability of a direct (affected or effected) object in the argument structure of the verbal base (cf. Picallo 1999: 382-383); the abstract noun may accordingly exhibit either the event (7a) or the result (7b) meaning:

(7) a. The evaluation ${ }_{\text {Event }}$ of the data of the investigation took place yesterday.

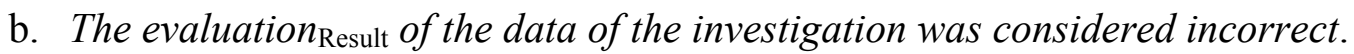

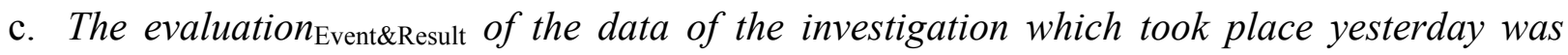
considered incorrect.

In the last decades, several attempts have been made along these lines with the aim of characterizing the polysemy in the terms of a semantic shift inherent in the abstract nouns as semantically complex types of nouns in the sense of Pustejovsky's (1995) dot nouns. The latter account for the fact (also common to other nouns) that abstract nouns may display more than one meaning at the same time, and in particular the eventive and the resultative, as shown by (7c) (cf. Gaeta 2015 for a discussion). On the other hand, the polysemy pattern observed in $(7 \mathrm{c})$ is not essentially different from that observed in other morphologically complex words and even in simplexes, e.g. in The paper Event\&Result that I don't understand is on the table. If the event / result polysemy is considered inherent, then the 
question arises as to whether this has consequences for the format of the single derivational processes forming abstract nouns or rather is a general feature characterizing natural languages. A similar question concerns the abstract result of an event, namely the fact/state shift, which is also identified by means of a passive(-like) meaning: agitation 'act of shaking / fact of being agitated, unrest'. Probably, the issue will have to be settled empirically. On the one hand, cases can be mentioned of abstract nouns going back to transitive verbs including a potentially effected object where no result meaning is possible like obtainment 'act of obtaining', but *'what is obtained', dismantlement 'act of dismantling', but *'what is dismantled', etc. (cf. Rainer 1993: 215 for similar Spanish examples). On the other, it has been suggested that the inherent shift might be valid only for specific subclasses of verbs, and in particular verbs of creation, re-description, mental action, emission, appearance and change of state or place. However, counterexamples like edification 'act of edifying', but *'what is edified' should make us leery of strong generalizations. The same applies to the fact/state shift, for which conceivable extensions are not attested like admiration 'act of admiring', but *'fact of being admired'. On the same vein, while one records a collective value for government 'act of governing' and 'persons responsible for governing', this conceivable extension is not found with domination 'act of dominating', but *'persons responsible for dominating'.

A further question relates to how the polysemy should be conceived, namely whether the process of meaning extension takes place at the lexical level or at the more general level of the conceptual representation of the word. In this sense, one could think that the lexical status of a complement might be of relevance, whether of argumental or of circumstantial nature. Unfortunately, this question must be answered in negative terms, because on the one hand there are cases like the Italian nouns semina 'sowing season' and affitto 'rent (cost)', based respectively on seminare 'to sow' and affittare 'to rent', in which the meaning extension refers to circumstantial information, while on the other there are derivatives like It. segatura 'sawdust', which does not refer to any argumental or circumstantial complement of the verbal base segare 'to saw'. The specific meaning can only become available if the complete narrative frame of the event of sawing is accessed including the waste produced by the process. This evidence speaks in favor of a (holistic) model of meaning which also includes our world knowledge about the single event and its narrative frame (cf. Rainer 1993: 215 for a discussion on the basis of Spanish examples). Whether this can be done by models inspired by the detailed level of encyclopedic information included into Pustejovsky's (1995) qualia structure has to remain an open question. It has to be added that further possible meanings of a quite idiosyncratic nature are found with other word-formation patterns like for instance the Catalan suffix -era that selects unergative verbs of the 1 st inflectional class and forms a desiderative abstract noun: plorar 'to cry' $\rightarrow$ plorera 'desire to cry', fumar 'to smoke' $\rightarrow$ fumera 'desire to smoke', etc. (cf. Gràcia \& Riera 2003). 
A final issue cross-cutting the abstract / concrete cline has been mentioned in (4) in §2.1.2 with regard to the simple vs. complex event nouns, namely pluralization. While the latter has been normally taken as a sign of increased typification and concretization, in fact several possibilities occur, as shown by the following examples taken from Italian (from the Internet):

(8) a. Numerose furono quindi le uccisioni di partigiani, ma anche di persone indifese come donne, vecchi e bambini.

'Numerous were then the killings of partisans, but also of helpless people, like women, old persons and children'.

b. Le uccisioni di Bob Kennedy e Martin Luther King da parte di fanatici destrorsi aprirono la strada all'elezione di Nixon.

'The killings of Bob Kennedy and Martin Luther King by rightist fanatics opened the way to the election of Nixon'.

c. Per fattori "interni", si intendono gli indebolimenti delle difese dell'organismo, come l'indebolimento della razza per inseguire selezioni genetiche spinte a perseguire record di produzione.

'By "internal" factors are meant the weakenings of the body's protections, as for instance the weakening of the race in order to go after genetic selections aiming at pursuing a production record'.

Pluralization of an abstract noun displays different effects depending on the semantic profile of the verbal bases involved as well as of the syntactic environment surrounding the abstract noun (cf. Lombard 1930: 96-105, Lüdtke 1978: 75-77, Roodenburg 2010, Knittel 2011). In general, its semantic effect normally consists in multiplying the number of the events described by the base predicate with an effect of iterativity or habituality (8a); in this way, it behaves like a pluractional operator expressing a multiplicity of events (cf. Cabredo Hofherr \& Laca 2012). A second possible interpretation of a pluralized abstract noun is distributive in the sense that it refers to an action taking place independently with respect to several distinct individuals explicitly mentioned in the text (8b), and finally a pluralized abstract noun can refer to different instantiations of the same action which is decomposed on a scale of nuances $(8 \mathrm{c})$. 


\subsubsection{Semantic properties of the verbal base}

One last issue concerns the selectivity of word-formation patterns forming abstract nouns with regard to the semantic properties of the verbal base. It has been said in $§ 2.1 .3$ that abstract nouns normally display a basic eventive meaning, more or less reflecting the meaning of the verbal base (cf. Kiefer 1998). The latter varies in a multi-faceted way but can be well tailored adopting Vendler's (1967) four actional classes, namely states, activities, accomplishments and achievements. They are generally characterized by referring to the three semantic features: $[ \pm$ dynamic $],[ \pm$ durative $]$ and $[ \pm$ telic] which define the actionality or Aktionsart of the verbal bases, not to be confounded with the aspect, which is its discourse-framed representation. Accordingly, a telic predicate like an accomplishment can be represented as imperfective (and in this sense: detelicized, unbounded) in a given context: Mary was painting her room when her grandfather died. Given its lexical nature, it is not surprising that actionality will be of particular relevance for word-formation. On the other hand, it has to be added that actionality cannot be measured out exclusively at the lexical level, but also requires the reference to the syntactic level, namely to the level of argument realization. This is so because the presence of arguments, and typically of objects, may provide a telic value to an activity, especially when they are explicitly 'quantized' (cf. Krifka 1992), as in to smoke a cigarette in contrast to to smoke (cigarettes). Accordingly, the former depicts an achievement and the latter an activity.

The three actional features can help us to better specify what eventive meaning concretely means when applied to abstract nouns. In fact, the three features enter both into the selection of the possible verbal bases with regard to the single derivational patterns and into the determination of the final meaning of the abstract nouns. In this way, the selectional properties of the single derivational patterns can be nicely isolated, insofar as the features may either carve out a set of verbal bases sharing the same property which is subsequently inherited by the abstract noun, or form abstract nouns showing detectable shifts of the values displayed by their verbal bases. In the first case, one can speak of the inner actionality of the derivational pattern which selects a specific set of verbs, and in the second case of the outer actionality which is different from the verbal base (cf. Brinton 1995, Gaeta 2000, 2002, 2015, Alexiadou 2010). Especially when more word-formation patterns give rise to abstract nouns on the basis of the same verb, their semantic profile can be neatly observed. Furthermore, the latter is particularly evident when syntactic tests are employed relating to their possible modifiers or to the predicates they can be combined with (the so-called container predicates mentioned in §3.1.1, cf. Bartsch 1986, Gaeta 2000, 2002: 114-126 and Huyghe \& Marín 2007).

To make one example, the stative verbs, that are characterized by the feature [- dynamic], stand in neat contrast to the dynamic verbs insofar as their corresponding abstract nouns are mostly selected 
in Italian by the suffix -anza/-enza (cf. Gaeta 2002: chap. 4, but similar data are also available for the French and Spanish cognate suffixes, cf. respectively Dal \& Namer 2010, and the NGLE 2009: 405): It. abbondare 'to abound' $\rightarrow$ abbondanza 'abundance', It. preferire 'to prefer' $\rightarrow$ preferenza 'preference', etc. In the case two homonymous verbs displaying different actional values occur, only the stative ones form the abstract nouns by means of this suffix, while the others select other derivational patterns:

(9) a. competere ${ }_{1}$ 'to be under the jurisdiction of' $\rightarrow$ competenza 'competence', conseguire ${ }_{1}$ 'to follow' $\rightarrow$ conseguenza 'consequence', discendere 1 'to come from' $\rightarrow$ discendenza 'descent, offspring', etc.

b. La competenza / *competizione a Laura del posto di direttore è fuori discussione.

'Laura's entitlement to the post as director is beyond doubt.'

c. competere $_{2}$ 'to compete' $\rightarrow$ competizione 'competition', conseguire 2 'to obtain' $\rightarrow$ conseguimento 'attainment', discendere ${ }_{1}$ 'to climb down' $\rightarrow$ discesa 'drop', etc.

d. La* competenza / competizione di Laura e Andrea per il posto di direttore è molto forte.

'The competition between Laura and Andrea for the place as director is very hard.'

In these pairs of Italian abstract nouns, the former - competenza, conseguenza and discendenza - are based on the stative meaning of the verbs (9a), while the latter - competizione, conseguimento and discesa - on the dynamic ones (9c). The corresponding abstract nouns reflect the opposition between the stative meaning selecting -enza $(9 \mathrm{~b})$ and the dynamic one selecting -zione $(9 \mathrm{~d})$.

Moreover, the abstract nouns inherit the stative actionality of the base verbs insofar as they are only compatible with those (imperfective) container predicates which do not focus on a telic state of affairs:

a. La competenza a Laura del posto di direttore durò fino alla sua pensione.

'Laura's entitlement to the post as director lasted until her retirement.'

b. *La competenza a Laura del posto di direttore si compì in due anni.

'Laura's entitlement to the post as director took place in two years.'

In the latter example, the perfective container predicate has to focus on a final state which cannot be brought about by the abstract noun. Clearly, when in this case one speaks of an "eventive" value of the abstract noun, one roughly means that the abstract nouns inherit the inner non-dynamic actionality 
of their verbal bases. This has to be kept distinct from what has been said in $\S 2.1 .3$ about the possible semantic shift event $>$ fact/state characterizing abstract nouns that are not necessarily built on stative verbs.

A second example in which the outer actionality of the abstract noun is modified with regard to verbal base is exemplified by Romanian, in which the so-called supine can be shown to provide telic verbal bases with a habitual reading which make them compatible with a prepositional phrase normally focusing on the unbounded character of the event like timp de 'for (X time)' (cf. Alexiadou, Iordăchioaia \& Schäfer 2011):

(11) a. sosit-ul lui Ion cu intîrziere timp de 3 ani

arrive.SUP-DEF his John with delay for 3 years

'John's (habit of) arriving late for 3 years'

b. ?? Sosire-a lui Ion cu intîrziere timp de 3 ani

arrive.INF-DEF his John with delay for 3 years

This habitual meaning is not found with the so-called long infinitive which also forms abstract nouns from telic verbs (11b).

\subsubsection{Abstract deadjectival and denominal nouns}

Since adjectives are normally used in predicative function giving rise to stative predicates, it does not come out as a surprise that a certain overlapping is often observed between action nouns and quality nouns, i.e. abstract deadjectival nouns. In particular, since many Italian adjectives go back to a Latin present participle they normally form their abstract noun with the help of the same suffix observed in $\S 2.1 .4$ for Italian stative verbs: arrogante 'arrogant' $\rightarrow$ arroganza 'arrogance', prepotente 'overbearing' $\rightarrow$ prepotenza 'overbearance', etc. In fact, stative verbs display an equivalence between the full verb and the periphrasis formed by the present participle and the copula: Gianni dipende / $\grave{e}$ dipendente da sua madre 'Gianni depends / is dependent on his mother', which accounts for the deadjectival/deverbal bivalence of many such abstracts: la dipendenza di Gianni da sua madre 'Gianni's dependence on his mother' (cf. Gaeta 2002: 145). Similar considerations hold for the overlapping with result nouns, even in cases in which a deverbal derivation is straightforward like for example with the Spanish derivative aislamiento 'isolation, state / condition of being isolated, isolatedness' based on aislar 'to isolate' which serves as quality noun for the participle aislado 
'isolated'. As already hinted at above, semantic shifts can also be understood as reflecting such kind of derivational relations insofar as the theoretically possible derivative *aisladez 'isolatedness' is odd and in fact blocked by the occurrence of aislamiento (cf. Rainer 2015: 1271). At any rate, deadjectival quality nouns are fairly widespread and often provide one of the most productive patterns found in a language, as shown for instance by the English nouns suffixed with -ness like lazy $\rightarrow$ laziness, the German nouns with -heit like schön 'beautiful' $\rightarrow$ Schönheit 'beauty', the Italian nouns with -ità like vero 'true' $\rightarrow$ verità 'truth', etc. (for a quantitative evaluation of their respective productivity, cf. Plag \& Baayen 2009, Schneider-Wiejowski 2009 and Gaeta \& Ricca 2006).

Similarly to the semantic shifts observed in (6) in $\$ 2.1 .3$, also quality nouns display a number of meaning extensions of a metonymic nature which refer to the concrete result of the property denoted by the base (12a), or the personification of the property $(12 \mathrm{~b})$, or the group delimited by the property (12c), the event connected with the property (12d), the time (12e), etc. (cf. Rainer 2015: 1276 for a discussion):

(12) a. sporco 'dirty' $\quad \rightarrow \quad$ sporcizia 'filth, dirth'

b. bello 'beuatiful' $\rightarrow \quad$ bellezza 'beauty, beautiful woman'

c. cristiano 'Christian' $\rightarrow \quad$ cristianità 'Christianity, Christians as a group'

d. antico 'antique' $\rightarrow$ antichità 'Antiquity, Ancient times'

e. avverso 'adverse' $\rightarrow$ avversità 'adversity, calamitous event'

Furthermore, another area of overlapping is given by abstract denominal nouns in particular referring to a status or a condition, the so-called status nouns. In this regard, they can be shown to exploit similar derivational procedures of deverbal nouns like for instance in the case of the Italian suffix (t)ura found in avvocato 'lawyer' $\rightarrow$ avvocatura 'attorneyship', magistrato 'judge' $\rightarrow$ magistratura 'judiciary', which is also found in deverbal abstract nouns like asciugare 'to dry' $\rightarrow$ asciugatura 'drying', leggere 'to read' $\rightarrow$ lettura 'reading', etc. On the other hand, since status nouns refer to a condition they are often based on derivational procedures also employed for deriving quality nouns like in the case of the German suffix -schaft found in deadjectival and denominal derivatives like eigen 'own' $\rightarrow$ Eigenschaft 'property', Freund 'friend' $\rightarrow$ Freundschaft 'friendship', which is also commonly found in Anwalt 'lawyer' $\rightarrow$ Anwaltschaft 'attorneyship', Richter 'judge' $\rightarrow$ Richterschaft ‘judiciary', etc.

\section{The label collective in morphology}


The label collective is generally employed in morphology for "comprehensive designations of plurality" (cf. Paul [1880] 1891: 295). This is normally put in connection with nouns, while with verbal bases the label collective has been marginally used for cases where a pluractional interpretation can be assumed (cf. Cabredo Hofherr \& Laca 2012).

\subsection{Collective as an inflectional feature}

The term collective is often used in connection with number. In particular, collective is distinct from plural insofar as " $[\mathrm{t}]$ he primary function of collectives is to specify the cohesion of a group, sometimes manifested in joint activity. Cohesion presupposes a multiplicity of group members. Thus a fleet of canoes (collective) must contain more than one canoe" (Corbett 2000: 119). As argued by Corbett, collective markers do not express plurality per se - they "are not basic number values" - and in fact they can be shown co-occur with a plural marker. For instance, in Yana, a Hokan language of Northern California, a collective suffix -wi is found which can be used to form (singular) mass nouns as in Pi- 'tree, stick' $\rightarrow$ ' $i$-wi 'firewood, wood' (cf. Sapir [1917] 1990: 210), or in combination respectively with the dual suffix $-u$ : and with the plural infixes $-t^{\prime}-$ and $-t^{\prime}-$ :

(13) a. dal 'hand'

$\rightarrow \quad d a l-u:-w i$ 'two hands (lit. hand-DU-COLL)'

lal 'foot'

$\rightarrow \quad l a l-u:-w i$ 'two feet (lit. foot-DU-COLL)'

b. si:win' $i$ 'yellow pine' $\rightarrow \quad s i-t$ '-in' $i$-wi 'yellow pines (lit. yellow:pine[PL]-COLL)' mugalā'i 'log' $\rightarrow \quad m u-t^{\prime}$-galā' $i-w i{ }^{\prime} \operatorname{logs}(\operatorname{lit} . \log [\mathrm{PL}]-\mathrm{COLL}){ }^{\prime}$

In Zuni, an isolate language spoken in New Mexico, a collective suffix can be combined either with a singular suffix or with a plural suffix, giving rise respectively to a singular collective noun or to a plural noun designating a multiple set (cf. Mithun 1999: 92):
(14) a. lu 'ash'
$\rightarrow \quad l u-t_{-}{ }^{2} e$ 'ashes in an ashtray, lit. ash-COLL-SG'
$s a$ 'bone'
$\rightarrow \quad s a-t p o-n$ 'skeleton, lit. bone-COLL-SG'
he 'metal' $\quad \rightarrow \quad$ ha-tpo-nne 'bridle bit, lit. metal-COLL-SG'
$c^{2}$ ina 'paper, letter' $\rightarrow \quad c^{?}$ ina- $p-^{?} e$ 'papers in a drawer, lit. paper-COLL-SG'
b. mo 'spherical object' $\rightarrow \quad m o-p a-w e^{2}$ 'truckloads of melons, lit. sphere-COLL-PL'
$s a$ 'bone' $\quad \rightarrow \quad s a-p a t a-w e^{?}$ 'very skinny people, lit. bone-COLL-PL' 
In (14a) the quite complex set of nominal collective suffixes - $ł a$, - $t p o,-p a$ and -pała, which specify a collection of objects respectively in a shallow container, in an arrangement (stack, bundle), in a deep container, and in a wrapped bundle, are shown to be combined with the singular suffixes $-{ }^{?} e,-n$ and -nne, while the same collective nouns can also be combined with the plural suffix $-w e^{?}$ and designate multiple sets (14b).

Moreover, in contrast to plurals the collective markers are generally not obligatory. This raises the question whether they should be considered to be part of inflectional or derivational morphology. Probably, there is no clear-cut distinction to be drawn here. One important property which can help us discriminating between the two options is their degree of generality of application. In this regard, collective markers can be shown in certain cases to have generalized to plural markers as for instance in Macedonian where many nouns of all genders can form collective plurals with the suffix -je- which inflect like singulars but require plural agreement. In the following example, the collective based on the noun list 'leaf' is used instead of the plural listovi (cf. Friedman 2002: 16):

\section{(15) Lis-je-to se veḱe požolteni. \\ leaf-COLL-DEF.SG are.PRS.3PL already yellowed.PL \\ 'The leaves are already yellowed'.}

Note that the plural forms in -ja also found with these collectives as for instance in the quadruple loza 'vine' / lozi 'vines (pl.)' / lozje 'vines, vineyard (coll.)' / lozja 'vineyards (coll. pl.)' are not widely used in the standard language, to the effect that the collective really serves as an alternative expression of plurality (cf. also Lunt 1952: 31).

On the other hand, we also observe the opposite development whereby an original plural marker has evolved into a collective marker flanking the marker for countable plurality. This is the case of the Italian suffix - $a$ coming from the Latin plural marker characterizing neuter nouns like folium / folia 'sheet(s)', filum / filla 'thread(s)', etc. (cf. Giacalone Ramat 1998: 113). As a consequence of the loss of the neuter gender in Italian, these nouns passed either to the masculine class: foglio / fogli 'sheet(s)', filo / fili 'thread(s)', or to the feminine class because the plural ending - $a$ was reanalyzed as the typical marker of singular feminine nouns like ros-a / ros-e 'rose(s)' to the effect that the feminine plural - $e$ was added: foglia 'leaf' / foglie 'leaves', fila / file 'row(s)'. However, especially in the case of neuter nouns for which a collective interpretation was available as in nouns designating natural pairs like Lat. brāchium / brāchia 'arm(s)' and cilium / cilia 'eyelid(s)', the marker - $a$ was retained with a collective value but flanked by the new countable masculine plurals bracci 'arms, 
branches' and cigli 'edges' corresponding to the masculine gender assigned to the singulars braccio 'arm, branch' and ciglio 'eyelash, edge'. However, the plural collective forms braccia 'arms' and membra 'eyelashes' developed a feminine gender, which reminds us of the feminine reanalysis of the Latin plurals folia and filla seen above. Interestingly, the new collective plural - $a$ assigning feminine gender was extended to a number of earlier masculine nouns in which it expresses collective value opposed to the countable plural as in the triples muro 'wall' / muri 'walls (pl.)' / mura 'walls (coll.)' and dito 'finger' / diti 'fingers (pl.)' / dita 'fingers (coll.)' coming respectively from Lat. digitus / digitī 'finger(s)' and mürus / mūrì 'wall(s)'.

As for verbs, the label collective has been used in connection with affixes displaying an iterative or frequentative value as in the case of the suffix -va found in Karuk, an isolate language spoken in California, normally used to multiply actions as in vík-pa $\theta$ 'to weave around (once)' $\rightarrow$ vikpá $\theta$-va 'to weave around and around', which can also indicate a plural subject as in pasnáp-iš(rih) 'to glue down (one)' / pasnapi 'šri hh-va 'to glue down (several)' (cf. Mithun 1988: 216), or in the case of the Latin suffix -it- found in clāmō 'to shout', rogō 'to ask' $\rightarrow$ clām-it-ō, rog-it-ō 'to shout, ask repeatedly', or of the Russian suffix -iv-found in strěljat' 'to fire one shot' $\rightarrow$ strěl-iv-at' 'to fire several shots'. Also reduplication is normally used for this purpose as shown by Southern Paiute verbs like $i v i$ - 'to drink' $\rightarrow i^{\prime} i$ ' $p \cdot i$ ' ‘drinks repeatedly, sips' (cf. Mithun 1988: 221). In all these examples, the pluractional meaning of the derivative can in fact be understood as a collection of repeated events (cf. Jespersen 1924: 210). A subtler case is provided by the collective suffix - $p c a$ found in Sahaptin, a Sahaptian language spoken in Washington and Oregon, in which the suffix specifies the involvement of the agents cooperating in a concerted action (16a) or of the patients affected or manipulated together as a set (16b) (cf. Mithun 1999: 92):

$\begin{aligned} \text { (16) a. }-w i \text { - 'to fall' } & \rightarrow \quad i x a ́-p c a-w i-y a \text { 'a bunch fell down accidentally' } \\ \text { b. }-n p \text { - 'to take' } & \rightarrow \quad i-p c a-n p-a \text { 'he took a bunch' }\end{aligned}$

In Yana the collective suffix - ${ }^{2} y u d$ - specifies that the subject has a dual reference: $s u{ }^{?} y u d-s a^{?} a s$ 'they both (only two) went off', while in Bella Coola, a Salish language of British Columbia, the reciprocal suffix $-\max ^{w}$ found for instance in satixmt-max ${ }^{w}$ 'to be each other's pals' is also used for referring to a collective subject: ' atpst-max w 'to eat together' (cf. Mithun 1999: 93).

Finally, as for the minor lexical classes the collective numerals found in Slavic languages have to be mentioned like for instance the Russian forms dvoe, troe, četvero, pjatero, etc. based on the cardinals $d v a / d v e$ 'two', tri 'three', četyre 'four', pjat' 'five', etc. These are especially used in combination with plural-only nouns like troe pochorot 'three funerals', and with animate masculine nouns like 
troe mal'čikov 'three boys' emphasizing the cohesiveness of the group in contrast with the individualizing nature of the cardinals (cf. Wade 2011: 221-223).

\subsection{Collective nouns in word-formation}

It has been observed in $\S 2.1 .3$ that collective meaning results from semantic shifts from action, quality and status nouns insofar as they turn out - via a metonymic meaning shift - to refer to a group or set of individuals displaying the property or condition designated by the base. Besides Anwaltschaft and Richterschaft mentioned in $\$ 2.1 .5$ which can also have a collective value, further derivatives with schaft with pure collective meaning are Beamte 'civil servant' $\rightarrow$ Beamtenschaft 'civil servants', Lehrer 'teacher' $\rightarrow$ Lehrerschaft 'teaching staff', etc. (cf. Mihatsch 2015). Moreover, a collective value can also result from semantic shifts typically found with action nouns like the case of administration seen in $\S 2.1 .3$, or with place names like for instance in the case of the Italian suffix eto which primarily refers to a place where the plants designated by the base are found and secondarily to the set of plants found in the place: limone 'lemon tree' $\rightarrow$ limoneto 'lemon-tree grove', pero 'pear tree' $\rightarrow$ pereto 'pear-tree grove', etc.

On the other hand, purely collective meaning can be expressed by specific affixes like for instance the German prefix ge- found in denominal collectives like Horn 'horn' $\rightarrow$ Gehörn 'horns', Tier 'animal, beast' $\rightarrow$ Getier 'animals', etc. (Fleischer \& Barz 1992: 200), or the Italian suffix -ame which can be combined with nominal bases and to a lesser extent with adjectival bases as respectively in bestia 'beast' $\rightarrow$ bestiame 'livestock', pentola 'pot' $\rightarrow$ pentolame 'pots', and in minuto 'tiny' $\rightarrow$ minutame 'tiny things', trito 'minced' $\rightarrow$ tritame 'minced food' (Grossmann 2004: 246). If the nominal base has a human reference, the derivative also acquires a derogatory nuance which is not found with non-human bases: contadino 'farmer' $\rightarrow$ contadiname 'farmers', dottore 'doctor' $\rightarrow$ dottorame 'doctors', etc. That collectives can sometimes have an additional pejorative connotation is shown by several other cases, for instance in Russian trjap' $\ddot{e}$ 'rags' is based on trjapka 'cloth' (cf. Koptjevskaja-Tamm 2004: 1072). Note that besides nominal bases the German prefix ge-- combined with the suffix $-e-$ is also found with verbal bases and give rise to abstract nouns provided with a pluractional meaning insofar as they refer to the repetition of the events designated by the base: lachen 'to laugh' $\rightarrow$ Gelache 'laughing', reden 'to talk' $\rightarrow$ Gerede 'chatter', etc. which often display a pejorative nuance.

Given their semantic proximity to plurals, the issue arises whether derived collectives are countable or not, as also discussed in $\S 3.1$ with regard to the Macedonian suffix -je-. The answer to this question 
depends to a large extent on the referential properties of the designated entity, namely whether it can be conceptualized as a structured and homogeneous set consisting of the sum of similar elements organized in a well-structured entity. For instance, the German prefixed collectives Mauer 'wall' $\rightarrow$ Gemäuer 'masonry' and Bein 'bone' $\rightarrow$ Gebein 'bones, remains' are countable insofar as they refer to structured entities while Ader 'vein' $\rightarrow$ Geäder 'venation' and Blut 'blood' $\rightarrow$ Geblüt 'bloods' are not. Similar considerations also hold for the Italian suffix -ame insofar as pelle 'skin, hide' $\rightarrow$ pellame 'hides' is countable while muscolo 'muscle' $\rightarrow$ muscolame 'muscles' is not. In sparse cases the collective derivative is a plurale tantum as in the case of German Bruder 'brother' $\rightarrow$ Gebrüder 'brothers (pl.)' providing an alternative to the inflectional form Brüder used in particular in front of surnames as in die Gebrüder Grimm 'the Grimm brothers'.

A further source for collectives is given by compounds, especially from cases where the head consists of an affixoid like -ware as found in kitchenware, tableware, etc. In particular, the so-called cocompounds are increasingly frequent from continental Eurasia toward the east and consist of two nouns, neither of which is the head as shown by the following examples from Mordvin, a Uralic language of the Finno-Ugric family (cf. Wälchli 2005: 139, 236):

(17) a. t'et'a.t-ava.t

'parents'

father.PL-mother.PL

b.ponks.t-panar.t 'clothing, clothes'

trousers.PL-shirt.PL

The co-compound can contain either exhaustive members of a couple (17a) or typical members which are representative of a larger set of possibly heterogeneous entities (17b). Similarly, in Chuvash, a Turkic language spoken in Russia, co-compounding is used for deriving collective nouns from two individual nouns, each of which denotes a member of the collective: ulma-śyrla 'apple-berry(fruit)'. (cf. Koptjevskaja-Tamm 2004: 1072). Although it is not unknown in Europe and especially in IndoEuropean languages, as shown respectively by Basque anai-arrebak 'brothers and sisters', and by Lithuanian kójos-rankẽlès 'feet and hands' and especially Modern Greek anðr-ว-jin-ऽ 'the married

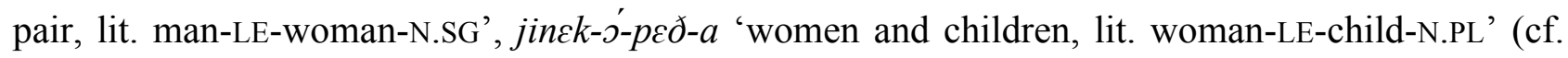
Wälchli 2005: 3), co-compounding is on the whole scarcely found. Besides sparse exceptions consisting of isolated forms like Old High German sunu-fatar-ungo 'son and father, lit. son-fatherNMLZ', the so-called relational compounds such as husband-wife pair or mother-child relationship found in several European languages are worth mentioning whose first parts come very close to true co-compounds (see Wälchli 2005: 8 for a discussion). 


\section{Conclusion}

Abstract and collective derivatives are conveniently placed in different onomasiological domains insofar as the former reflects a general process of transcategorization and abstraction in the very concrete sense of detaching a number of properties of the source category, while the latter has to be accommodated in the domain of number and plurality. Nevertheless, they display a certain area of overlapping because the semantic shifts observed in the respective domains converge towards shared onomasiological formats as shown by German collective nouns like Gebein 'bones' and Gerede 'chatter'. Especially in this latter example, the reference to a collection of abstract entities nicely exemplifies the process of convergence whereby the transcategorization is strictly combined with the pluractional interpretation of the deverbal noun. On the other hand, the reference to the abstract condition designated by the base lends itself as a convenient jumping-off place for the metonymic shift leading to the collective denomination of the group of entities characterized by the base property as shown by Italian cristianità 'Christianity' and German Anwaltschaft 'attorneyship'. This provides another path for the trade-off of abstract and collective meaning.

\section{Acknowledgements}

Thanks are due to Rochelle Lieber and to one anonymous reviewer for helpful and constructive comments.

\section{References}

Aarts, B. (2012). The subjunctive conundrum in English. Folia Linguistica 46(1), 1-20.

Alexiadou, A. (2010). Nominalizations: A Probe into the Architecture of Grammar. Part I: The Nominalization Puzzle. Language and Linguistics Compass, 4(7), 496-511.

Alexiadou, A., Iordăchioaia, G., \& Schäfer, F. (2011). Scaling the variation in Romance and Germanic nominalizations. In P. Sleeman \& H. Perridon (Eds.), The Noun Phrase in Romance and Germanic: Structure, Variation, and Change (pp. 25-40). Amsterdam, The Netherlands: John Benjamins. 
Apresjan, J. D. (1974). Regular Polysemy. Linguistics, 12, 5-32.

Bartsch, R. (1986). On Aspectual Properties of Dutch and German Nominalizations. In V. Lo Cascio \& C. Vet (Eds.), Temporal Structure in Sentence and Discourse (pp. 7-39). Dordrecht, The Netherlands: Foris.

Bauer, L. (1983). English Word-Formation. Cambridge, U. K.: Cambridge University Press.

Brinton, L. (1995). The aktionsart of English deverbal nominalizations. In P. M. Bertinetto, V. Bianchi, J. Higginbotham \& M. Squartini (Eds.), Temporal Reference, Aspect and Actionality (vol. 1, pp. 27-42). Torino, Italy: Rosenberg \& Sellier.

Cabredo Hofherr, P. \& Laca, B. (2012). Introduction - event plurality, verbal plurality and distributivity. In P. Cabredo Hofherr \& B. Laca (Eds.), Verbal Plurality and Distributivity (pp. 1-24). Berlin, Germany: De Gruyter.

Comrie, B. \& Thompson, S. A. (2007). Lexical nominalization. In T. Shopen (Ed.), Language Typology and Syntactic Description. Vol. 3: Grammatical Categories and the Lexicon. Second Edition (pp. 334-381). Cambridge, U.K.: Cambridge University Press.

Corbett, G. (2000). Number. Cambridge, U.K.: Cambridge University Press.

Dal, G., \& Namer, F. (2010). Les noms en -ance/-ence du français: quel(s) patron(s) constructionnel(s)? In. F. Neveu, V. Muni Toke, Th. Klingler, J. Durand, L. Mondada \& S. Prévost (Eds.), 2ème Congrès Mondial de Linguistique Française-CMLF 2010 (pp. 893-907). Paris, France: Institut de Linguistique Française.

Fleischer, W., \& Barz, I. (1992). Wortbildung der deutschen Gegenwartssprache. Tübingen, Germany: Niemeyer.

Friedman, V. A. (2002), Macedonian. München, Germany: Lincom Europa.

Gaeta, L. (2000). On the Interaction between Morphology and Semantics: The Italian Suffix -ATA. Acta Linguistica Hungarica, 47(1-4), 205-229.

Gaeta, L. (2002). Quando i verbi compaiono come nomi. Un saggio di morfologia naturale. Milano, Italy: Franco Angeli.

Gaeta, L. (2015). Action nouns in Romance. In P. O. Müller, I. Ohnheiser, S. Olsen \& F. Rainer (Eds.), Word-Formation. An International Handbook of the Languages of Europe (vol. 2, pp. 1209-1229). Berlin, Germany: De Gruyter Mouton.

Gaeta, L., \& Ricca, D. (2006). Productivity in Italian word formation: a variable-corpus approach. Linguistics, 44(1), 57-89.

Giacalone Ramat, A. (1998), Testing the boundaries of grammaticalization. In A. Giacalone Ramat \& P. J. Hopper (Eds.), The limits of grammaticalization (pp. 107-127). Amsterdam, The Netherlands: John Benjamins. 
Gràcia, L1., \& Riera, L. (2003). A propos des noms déverbaux avec le suffixe -era du catalan. Cahiers de Grammaire, 28, 153-161.

Grimshaw, J. (1990). Argument structure. Cambridge, Mass.: MIT Press.

Grossmann, M. (2004), Nomi collettivi. In M. Grossmann \& F. Rainer (Eds.), La formazione delle parole in italiano (pp. 244-252). Tübingen, Germany: Niemeyer.

Gruppe, O. F. [1831] (1954), Wort und Begriff "Abstraktum”. In H. Junker (ed.), Sprachphilosophisches Lesebuch. Heidelberg: Winter, 148-165.

Haspelmath, M. (2009). Terminology of Case. In A. Malchukov \& A. Spencer (Eds.), The Oxford Handbook of Case (pp. 505-517). Oxford, U.K.: Oxford University Press.

Haspelmath, M. \& Sims, A. D. (2009). Understanding Morphology. Second Edition. London, U. K.: Hodder Education.

Huyghe, R., \& Marín, R. (2007). L'héritage aspectuel des noms déverbaux en français et en espagnol. Faits de Langues, 30, 265-274.

Jespersen, O. (1924). The Philosophy of Grammar. London, U. K.: Allen \& Unwin.

Kiefer, F. (1998). Les substantifs déverbaux événementiels. Langages, 32(131), 56-63.

Knittel, M. L. (2011). French event nominals and number-inflection. Recherches linguistiques de Vincennes, 40, 127-148.

Koptjevskaja-Tamm, M. (1993). Nominalizations. London, U. K.: Routledge.

Koptjevskaja-Tamm, M. (2004). Mass and collection. In G. Booij, Ch. Lehmann, J. Mugdan \& S. Skopeteas (Eds.), Morphology. An International Handbook on Inflection and Word-Formation (vol. 2, pp. 1067-1073). Berlin, Germany: Walter de Gruyter.

Krifka, M. (1992). Thematic Relations as Links between Nominal Reference and Temporal Constitution. In I. Sag \& A. Szabolcsi (Eds.), Lexical Matters (pp. 29-53). Stanford: CSLI.

Langacker, R. W. (1987). Nouns and Verbs. Language, 63(1), 53-94.

Lehmann, Ch. (1982). Nominalisierung: Typisierung von Propositionen. In H. Seiler \& Ch. Lehmann (Eds.), Apprehension. Das sprachliche Erfassen von Gegenständen. Teil I: Bereich und Ordnung der Phänomene (pp. 66-83). Tübingen, Germany: Narr.

Lehmann, V. (2015). Categories of word-formation. In P. O. Müller, I. Ohnheiser, S. Olsen \& F. Rainer (Eds.), Word-Formation. An International Handbook of the Languages of Europe (vol. 2, pp. 1020-1034). Berlin, Germany: De Gruyter Mouton.

Lombard, A. (1930). Les constructions nominales dans le français moderne. Étude syntactique et stylistique. Uppsala, Stockholm, Sweden: Almqvist \& Wiksell.

Lüdtke, J. (1978). Prädikative Nominalisierungen mit Suffixen im Französischen, Katalanischen und Spanischen. Tübingen, Germany: Niemeyer. 
Lunt, H. G. (1952). Grammar of the Macedonian Literary Language. Skopje.

Lyons, J. (1977). Semantics. Cambridge, U. K.: Cambridge University Press.

Mackenzie, J. L. (2004), Entity concepts. In G. Booij, Ch. Lehmann, J. Mugdan \& S. Skopeteas (Eds.), Morphology. An International Handbook on Inflection and Word-Formation (vol. 2, pp. 973-983). Berlin, Germany: Walter de Gruyter.

Mackenzie, J. L. (2007), Double-possessive nominalizations in English. In Ch. S. Butler, R. Hidalgo Downing \& J. Lavid (Eds.), Functional Perspectives on Grammar and Discourse. In honour of Angela Downing (pp. 217-231). Amsterdam, The Netherlands: John Benjamins.

Malchukov, A. (2004), Nominalization/verbalization: Towards a Typology of Transcategorial Operations. München, Germany: Lincom Europa.

Mihatsch, W. (2015). Collectives. In P. O. Müller, I. Ohnheiser, S. Olsen \& F. Rainer (Eds.), WordFormation. An International Handbook of the Languages of Europe (vol. 2, pp. 1183-1195). Berlin, Germany: De Gruyter Mouton.

Mithun, M. (1988). Lexical categories and the evolution of number marking. In M. Hammond \& M. Noonan (Eds.), Theoretical morphology (pp. 211-234). New York, NY: Academic Press.

Mithun, M. (1999). The languages of North America. Cambridge, U. K.: Cambridge University Press.

NGLE 2009 = Nueva Gramática de la Lengua Española. Madrid: Asociación de Academias de la Lengua Española, 2009.

Paul, H. [1880] (1891). Prinzipien der Sprachgeschichte. Halle, Germany: Niemeyer [Engl. transl. by H. A. Strong: Principles of the History of Language. London, U. K.: Longmans, Green \& Co.].

Picallo, M. C. (1999). La estructura del sintagma nominal: Las nominalizaciones y otros sustantivos con complementos argumentales. In I. Bosque \& V. Demonte (Eds.), Gramática descriptiva de la lengua española. Vol. 1: Sintaxis básica de las clases de palabras (pp. 363-393). Madrid, Spain: Espasa.

Plag, I., \& Baayen, R. H. (2009). Suffix ordering and morphological processing. Language, 85(1), $106-149$.

Porzig, W. (1930-31). Die Leistung der Abstrakta in der Sprache. Blätter für deutsche Philosophie, 4, 66-77. [repr. in H. Moser (Ed.), Das Ringen um eine neue deutsche Grammatik. Aufsätze aus drei Jahrzehnten (1929-1959) (pp. 255-268). Darmstadt, Germany: Wissenschaftliche Buchgesellschaft, 1969].

Pustejovsky, J. (1995). The Generative Lexicon. Cambridge, Mass.: MIT Press.

Rainer, F. (1993). Spanische Wortbildungslehre. Tübingen, Germany: Niemeyer. 
Rainer, F. (1996). La polysémie des noms abstraits: historique et état de la question. In N. Flaux, M. Glatigny \& D. Samain (eds.), Les noms abstraits. Histoire et théories (pp. 117-126). Villeneuve d'Ascq, France: Presses Universitaires du Septentrion.

Rainer, F. (2015). Quality nouns. In P. O. Müller, I. Ohnheiser, S. Olsen \& F. Rainer (Eds.), WordFormation. An International Handbook of the Languages of Europe (vol. 2, pp. 1268-1284). Berlin, Germany: De Gruyter Mouton.

Roodenburg, J. (2010). Plurality from a cross-linguistic perspective: the existence of plural arguments supporting nominalizations in French. Lingue e linguaggio, 9(1), 41-64.

Sapir, E. 1917. The position of Yana in the Hokan stock (University of California Publication in American Archaeology and Ethnology 13, 1-34). Berkeley: University of California. [Reprinted in W. Bright (ed.), The Collected Works of Edward Sapir (vol. 5, pp. 189-222). Berlin, Germany: De Gruyter Mouton, 1990].

Schneider-Wiejowski, R. (2009). Sprachwandel anhand von Produktivitätsverschiebungen in der schweizerdeutschen Derivationsmorphologie. Linguistik online, 38(2), 1-12.

Trost, K. (1976). Zur Definition der Abstrakta (am Beispiel von Russisch und Deutsch). Indogermanische Forschungen, 81, 221-39.

Vendler, Z. (1967). Linguistics in Philosophy. Ithaca: Cornell University Press.

Wade, T. (2011). A Comprehensive Russian Grammar. Third Edition. Revised and updated by David Gillespie. Malden \& Oxford, U. K.: Wiley-Blackwell.

Wälchli, B. (2005), Co-Compounds and Natural Coordination. Oxford, U. K.: Oxford University Press. 